\title{
Clopidogrel or ticagrelor in acute coronary syndrome patients treated with newer-generation drug-eluting stents: CHANGE DAPT
}

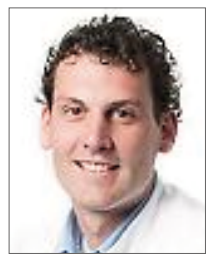

Paolo Zocca ${ }^{1}$, MD; Liefke C. van der Heijden ${ }^{1}$, MD; Marlies M. Kok ${ }^{1}$, MD; Marije M. Löwik ${ }^{1}$, PhD; Marc Hartmann ${ }^{1}, \mathrm{MD}$, PhD; Martin G. Stoel ${ }^{1}$, MD, PhD; J. (Hans) W. Louwerenburg ${ }^{1}$, MD; Frits H.A.F. de Man'1, MD, PhD; Gerard C.M. Linssen², MD, PhD; Iris L. Knottnerus ${ }^{3}, \mathrm{MD}, \mathrm{PhD}$; Carine J.M. Doggen ${ }^{4}, \mathrm{PhD}$; K. Gert van Houwelingen ${ }^{1}, \mathrm{MD}$; Clemens von Birgelen ${ }^{1,4 *}, \mathrm{MD}, \mathrm{PhD}$

\begin{abstract}
1. Department of Cardiology, Thoraxcentrum Twente, Medisch Spectrum Twente, Enschede, the Netherlands; 2. Department of Cardiology, Ziekenhuisgroep Twente, Almelo and Hengelo, the Netherlands; 3. Department of Neurology, Medisch Spectrum Twente, Enschede, the Netherlands; 4. Department of Health Technology and Services Research, MIRA Institute for Biomedical Technology and Technical Medicine, University of Twente, Enschede, the Netherlands
\end{abstract}

This paper also includes supplementary data published online at: http://www.pcronline.com/eurointervention/125th_issue/184

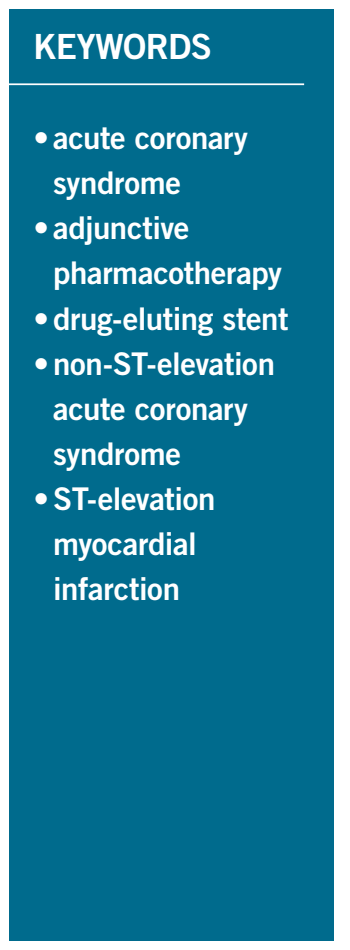

\begin{abstract}
Aims: Acute coronary syndrome (ACS) guidelines have been changed, favouring more potent antiplatelet drugs. We aimed to evaluate the safety and efficacy of a ticagrelor- instead of a clopidogrel-based primary dual antiplatelet (DAPT) regimen in ACS patients treated with newer-generation drug-eluting stents (DES).

Methods and results: CHANGE DAPT (clinicaltrials.gov: NCT03197298) assessed 2,062 consecutive real-world ACS patients, treated by percutaneous coronary intervention (PCI), the primary composite endpoint being net adverse clinical and cerebral events (NACCE: all-cause death, any myocardial infarction, stroke or major bleeding). In the clopidogrel (CP; December 2012-April 2014) and ticagrelor periods (TP; May 2014-August 2015), 1,009 and 1,053 patients were treated, respectively. TP patients were somewhat older, underwent fewer transfemoral procedures, and received fewer glycoprotein IIb/IIIa inhibitors. In the TP, the one-year NACCE rate was higher $(5.1 \%$ vs. $7.8 \%$; HR 1.53 [95\% CI: $1.08-2.17]$; $\mathrm{p}=0.02)$. Assessment of non-inferiority (pre-specified margin: 2.7\%) was inconclusive (risk difference: 2.64 [95\% CI: $\left.0.52-4.77] ; p_{\text {non-inferiority }}=0.48\right)$. TP patients had more major bleeding $(1.2 \%$ vs. $2.7 \% ; \mathrm{p}=0.02)$ while there was no benefit in ischaemic endpoints. Propensity score-adjusted multivariate analysis confirmed higher NACCE (adj. HR 1.75 [95\% CI: 1.20-2.55]; $\mathrm{p}=0.003$ ) and major bleeding risks during TP (adj. HR 2.75 [95\% CI: 1.34-5.61]; $\mathrm{p}=0.01)$.
\end{abstract}

Conclusions: In this observational study, the guideline-recommended ticagrelor-based primary DAPT regimen was associated with an increased event risk in consecutive ACS patients treated with newer-generation DES.

*Corresponding author: Thoraxcentrum Twente and University of Twente, Medisch Spectrum Twente, Department of Cardiology, Postbus 50.000,7500 KA Enschede, the Netherlands.E-mail: c.vonbirgelen@mst.nl 


\section{Abbreviations}

$\begin{array}{ll}\text { ACS } & \text { acute coronary syndrome } \\ \text { ARC } & \text { Academic Research Consortium } \\ \text { BMS } & \text { bare metal stent } \\ \text { CABG } & \text { coronary artery bypass grafting } \\ \text { CP } & \text { clopidogrel period } \\ \text { DAPT } & \text { dual antiplatelet therapy } \\ \text { DES } & \text { drug-eluting stent } \\ \text { MI } & \text { myocardial infarction } \\ \text { NACCE } & \text { net adverse clinical and cerebral events } \\ \text { PCI } & \text { percutaneous coronary intervention } \\ \text { STEMI } & \text { ST-segment elevation myocardial infarction } \\ \text { TIMI } & \text { Thrombolysis In Myocardial Infarction } \\ \text { TP } & \text { ticagrelor period }\end{array}$

\section{Introduction}

In patients with acute coronary syndrome (ACS), many of whom require percutaneous coronary intervention (PCI) with implantation of drug-eluting stents (DES), there is an indication for dual antiplatelet therapy (DAPT). Current international guidelines ${ }^{1,2}$ recommend the use of more potent $\mathrm{P}_{2} \mathrm{Y}_{12}$ inhibitors, such as ticagrelor or prasugrel, instead of the former standard of clopidogrel and aspirin. The pivotal trial that compared ticagrelor versus clopidogrel showed better clinical outcome for ticagrelor in a moderate to high-risk ACS population that comprised $39 \%$ of patients who did not undergo PCI during the index hospitalisation ${ }^{3}$. In addition, more than $60 \%$ of trial participants treated by PCI received bare metal stents (BMS), and most patients who received DES had first-generation devices ${ }^{3}$. Nevertheless, use of this more potent $\mathrm{P} 2 \mathrm{Y}_{12}$ inhibitor was associated with more major bleedings $\mathrm{s}^{3,4}$.

Meanwhile, newer-generation DES have become available with thinner stent struts covered by more biocompatible or biodegradable polymer coatings, and improved clinical outcome compared to BMS and first-generation DES $^{5-7}$. In clinical practice, most ACS patients are treated with newer-generation DES that showed favourable results with clopidogrel-based DAPT ${ }^{8,9}$. In the present study, we evaluate the impact of the guideline-recommended change in primary DAPT regimen to ticagrelor on one-year outcome in consecutive ACS patients treated with newer-generation DES at a high-volume PCI centre.

Editorial, see page 1133

\section{Methods}

\section{STUDY POPULATION AND DESIGN}

At the tertiary PCI centre Thoraxcentrum Twente in the Netherlands we performed an investigator-initiated, prospective observational study that assessed one-year outcome in 2,062 consecutive ACS patients, treated with newer-generation DES (CHANGE DAPT, NCT03197298). Patients were included between 21 December 2012 and 25 August 2015. On 1 May 2014, we followed international guidelines to replace clopidogrel- by ticagrelor-based primary DAPT. Group 1 patients were included before (clopidogrel period [CP]) and group 2 patients after this date (ticagrelor period [TP]). ACS patients $\geq 18$ years, treated with newer-generation DES, were included. Exclusion criteria were known pregnancy, life expectancy $<1$ year (i.e., no cardiogenic shock or post-resuscitation), planned elective surgery requiring DAPT interruption after $<6$ months, and known intolerance to DES components. As guidelines recommend clopidogrel use in patients on oral anticoagulation ${ }^{2}$, patients with oral anticoagulation at baseline were not included.

This observational study complied with the Declaration of Helsinki. According to Dutch law, and as approved by the Medical Ethics Committee Twente, written informed consent was not required.

\section{DEFINITIONS OF CLINICAL ENDPOINTS}

The primary endpoint net adverse clinical and cerebral events (NACCE) is a composite of all-cause death, any myocardial infarction (MI), stroke or major bleeding. Definitions of MI are according to the Academic Research Consortium (ARC) $)^{10,11}$. Strokes were a focal loss of neurologic function by an ischaemic or haemorrhagic event, with residual symptoms $\geq 24$ hours or leading to death. Bleeding ARC (BARC) and Thrombolysis In Myocardial Infarction (TIMI) bleeding criteria were used ${ }^{12,13}$. Major bleeding was any BARC class 3 or 5 bleeding and/or all TIMI major bleedings (i.e., coronary artery bypass grafting [CABG] and non-CABG-related).

Secondary endpoints were individual components of the primary composite endpoint, any clinically indicated revascularisation by $\mathrm{PCI}$ or $\mathrm{CABG}$, definite or probable stent thrombosis according to $\mathrm{ARC}^{10}$, the composite of cardiac death, MI or stroke.

\section{CORONARY INTERVENTION AND MEDICAL THERAPY}

Interventional procedures were performed according to local clinical protocols. Unfractionated heparin was administered directly before PCI. Lesion preparation, stent post-dilation and use of glycoprotein IIb/IIIa inhibitors (generally limited to a single bolus of abciximab) were left to the operator's discretion. If patients were not on antiplatelet therapy, loading doses of aspirin $(\geq 300 \mathrm{mg}$ ) and clopidogrel $(600 \mathrm{mg})$ or ticagrelor $(180 \mathrm{mg})$ were administered before PCI. Timing of drug loading did not change during the study. Maintenance doses were 80-100 mg aspirin and $75 \mathrm{mg}$ clopidogrel daily, and/or $90 \mathrm{mg}$ ticagrelor twice daily. DAPT of patients referred from other hospitals generally remained unchanged. DAPT was generally prescribed for 12 months with the use of statins, beta-blockers, RAS inhibitors, and proton pump inhibitors as appropriate according to guidelines and the physician's judgement. If patients required oral anticoagulation during follow-up, ticagrelor was replaced by clopidogrel, and aspirin was generally stopped one month after PCI.

\section{CLINICAL FOLLOW-UP AND EVENT ASSESSMENT}

Information on clinical follow-up was obtained at visits to outpatient clinics and/or by mail or telephone. The contract research organisation Cardio Research Enschede (Enschede, the Netherlands) performed the study. During both DAPT periods, similar numbers of patients participated in a DES trial ${ }^{14}$ with independent data monitoring. Clinical events were adjudicated by a committee (three members of the research team), and strokes were assessed by an experienced neurologist. 


\section{STATISTICAL ANALYSIS}

Data were reported as frequencies and percentages or mean \pm standard deviation. Differences in dichotomous and categorical variables were assessed by chi-square test, while continuous variables were assessed with the Student's t-test. Kaplan-Meier analysis was used to calculate the time to clinical endpoints; the log-rank test was applied for between-group comparisons. Hazard ratios were computed using Cox proportional hazards regression analyses. For adjustment of potential confounders, a propensity score analysis was performed. Propensity scores were estimated using multiple logistic regression analysis. All baseline and procedural variables were used to calculate the propensity score for treatment in the TP; a multivariate Cox regression model was used to adjust for the propensity score.

The primary analyses compared the two treatment periods, CP versus TP. To assess non-inferiority, a NACCE rate of $6.5 \%$ was assumed in both periods (i.e., CP and TP), based on the data from the OPTIMIZE, TWENTE and DUTCH PEERS trials ${ }^{8,9,15}$. With a one-sided alpha level of 0.05 and at least $80 \%$ power, a sample size of 1,031 patients in each group was required to demonstrate non-inferiority with a margin of $2.7 \%$, based on the OPTIMIZE trial $^{15}$. Non-inferiority would be achieved if the upper limit of the one-sided $95 \%$ confidence interval of the absolute risk difference was less than the non-inferiority margin.

Additional sensitivity analyses were performed, in which patients actually treated with clopidogrel during the $\mathrm{CP}$ were compared to patients actually treated with ticagrelor during the TP. Treatment by either clopidogrel or ticagrelor was assessed at discharge or, if a NACCE occurred before discharge, at the time of that in-hospital event.

Except for the non-inferiority analysis, $p$-values and confidence intervals were two-sided; p-values $<0.05$ were considered significant. Sample size calculation was performed with PASS (NCSS, Kaysville, UT, USA), and data analysis with SPSS, Version 22.0 (IBM Corp., Armonk, NY, USA).

\section{Results}

\section{STUDY POPULATION}

Of all 2,062 patients enrolled, 1,009 (48.9\%) were treated during the CP versus 1,053 (51.1\%) during the TP (Figure 1). Most patient demographic and clinical characteristics (Table 1) were similar for both periods, including the proportion of STEMI (44.8\% vs. $41.2 \%)$. TP patients were somewhat older $(62.9 \pm 11.6$ vs. $63.9 \pm 12.1$ years, $\mathrm{p}=0.04)$ and less often diagnosed with peripheral artery disease $(8.8 \%$ vs. $5.5 \%, \mathrm{p}=0.003)$.

\section{INTERVENTIONAL PROCEDURE}

Details of PCI and medication are shown in Table 2. Multivessel treatment and stent type did not differ between periods, but transradial access was more common during the TP $(17.7 \%$ vs. $44.6 \%, \mathrm{p}<0.001)$.

\section{MEDICATION}

The use of glycoprotein IIb/IIIa inhibitors decreased from CP to TP (43.7\% vs. $24.7 \%, \mathrm{p}<0.001$ ) (Table 2). More TP patients were treated with a proton pump inhibitor at discharge $(42.6 \%$ vs. $55.1 \%, \mathrm{p}<0.001)$.
2,062 consecutive patients with acute coronary syndrome treated with never-generation drug-eluting stents

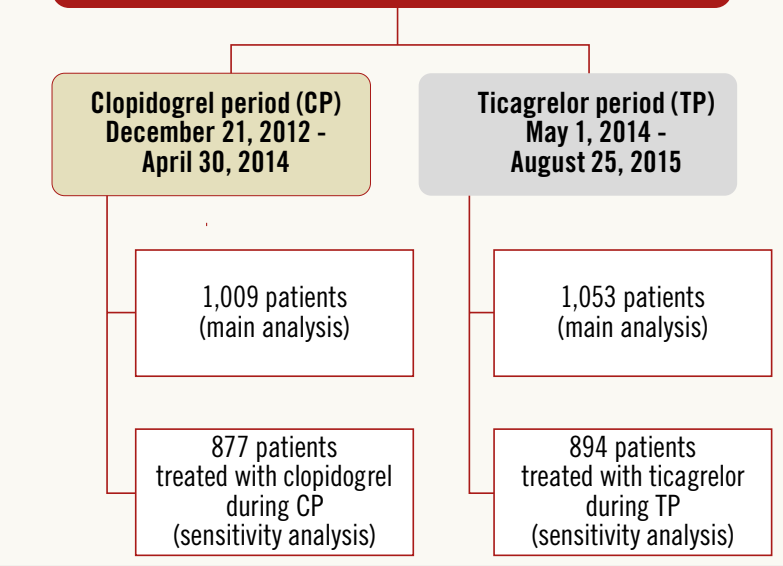

Figure 1. Flow chart. Exact number of patients not fulfilling inclusion criteria not available.

During the CP, 877/1,009 (86.9\%) patients were treated with clopidogrel at discharge, while 132/1,009 (13.1\%) were on ticagrelor. At one-year follow-up, 916/1,009 (90.8\%) CP patients were still on DAPT: $78.7 \%$ used clopidogrel and $12.1 \%$ ticagrelor; a combination of oral anticoagulant with $\mathrm{P}_{2} \mathrm{Y}_{12}$ inhibitor was prescribed in $42 / 1,009$ (4.2\%).

Table 1. Baseline characteristics.

\begin{tabular}{|c|c|c|c|}
\hline & \multicolumn{3}{|c|}{ All patients $(n=2,062)$} \\
\hline & $\begin{array}{c}\text { Clopidogrel } \\
\text { period (CP) } \\
n=1,009\end{array}$ & $\begin{array}{c}\text { Ticagrelor } \\
\text { period (TP) } \\
n=1,053\end{array}$ & $p$-value \\
\hline Age, years & $62.9 \pm 11.6$ & $63.9 \pm 12.1$ & 0.04 \\
\hline Male sex & $702(69.6)$ & $748(71.0)$ & 0.47 \\
\hline BMI, $\mathrm{kg} / \mathrm{m}^{2 *}$ & $27.4 \pm 4.3$ & $27.7 \pm 4.4$ & 0.13 \\
\hline \multicolumn{4}{|l|}{ Clinical history } \\
\hline Hypertension & $428(42.4)$ & $440(41.8)$ & 0.77 \\
\hline Hypercholesterolaemia & $360(35.7)$ & $384(36.5)$ & 0.71 \\
\hline Diabetes mellitus & $158(15.7)$ & $186(17.7)$ & 0.22 \\
\hline Peripheral artery disease & $89(8.8)$ & $58(5.5)$ & 0.003 \\
\hline Chronic obstructive pulmonary disease & $78(7.7)$ & $83(7.9)$ & 0.90 \\
\hline Previous MI & $146(14.5)$ & $151(14.3)$ & 0.93 \\
\hline Previous PCl & $166(16.5)$ & $174(16.5)$ & 0.97 \\
\hline Previous CABG & $72(7.1)$ & $63(6.0)$ & 0.29 \\
\hline Previous stroke & $32(3.2)$ & $31(2.9)$ & 0.76 \\
\hline Previous gastrointestinal bleeding & $11(1.1)$ & $15(1.4)$ & 0.50 \\
\hline Renal insufficiency & $40(4.0)$ & $38(3.6)$ & 0.67 \\
\hline Dialysis & $9(0.9)$ & $6(0.6)$ & 0.39 \\
\hline \multicolumn{4}{|l|}{ Clinical presentation } \\
\hline ST-elevation MI & $452(44.8)$ & $434(41.2)$ & 0.10 \\
\hline Non-ST-elevation MI & $256(25.4)$ & $292(27.7)$ & 0.23 \\
\hline Unstable angina & $301(29.8)$ & $327(31.1)$ & 0.55 \\
\hline
\end{tabular}


Table 2. Procedural characteristics and medication.

\begin{tabular}{|c|c|c|c|c|}
\hline & \multicolumn{3}{|c|}{ All patients $(n=2,062)$} \\
\hline & & $\begin{array}{l}\text { Clopidogrel } \\
\text { period (CP) } \\
n=1,009\end{array}$ & $\begin{array}{c}\text { Ticagrelor } \\
\text { period (TP) } \\
n=1,053\end{array}$ & $p$-value \\
\hline \multicolumn{5}{|c|}{ Procedural characteristics } \\
\hline \multirow{2}{*}{$\begin{array}{l}\text { Arterial } \\
\text { access }\end{array}$} & Radial & $179(17.7)$ & $470(44.6)$ & $<0.001$ \\
\hline & Femoral & $830(82.3)$ & $583(55.4)$ & \\
\hline \multirow{3}{*}{$\begin{array}{l}\text { Vessel } \\
\text { disease }\end{array}$} & 1 & $550(54.4)$ & $603(57.3)$ & \multirow{3}{*}{0.35} \\
\hline & 2 & $310(30.7)$ & $294(27.9)$ & \\
\hline & 3 & $149(14.8)$ & $156(14.8)$ & \\
\hline \multicolumn{2}{|c|}{ Multivessel treatment } & $176(17.4)$ & $181(17.2)$ & 0.88 \\
\hline \multicolumn{2}{|c|}{ Glycoprotein Ilb/Illa inhibitor } & $441(43.7)$ & $260(24.7)$ & $<0.001$ \\
\hline \multirow{4}{*}{$\begin{array}{l}\text { Stent } \\
\text { type }\end{array}$} & Co-Cr SES & $268(26.6)$ & $290(27.5)$ & \multirow{4}{*}{0.21} \\
\hline & Co-Cr ZES & $426(42.2)$ & 455 (43.2) & \\
\hline & Pt-CrEES & $307(30.4)$ & $306(29.1)$ & \\
\hline & Other newer-generation DES & $8(0.8)$ & $2(0.2)$ & \\
\hline \multicolumn{5}{|c|}{ Medication at discharge } \\
\hline \multicolumn{2}{|c|}{ Aspirin } & $1,009(100)$ & $1,053(100)$ & \\
\hline \multicolumn{2}{|c|}{ Clopidogrel } & $877(86.9)$ & $159(15.1)$ & \\
\hline \multicolumn{2}{|c|}{ Ticagrelor } & $132(13.1)$ & $894(84.9)$ & \\
\hline \multicolumn{2}{|l|}{ Statin } & $961(95.2)$ & $992(94.2)$ & 0.29 \\
\hline \multicolumn{2}{|c|}{ Beta-blocker } & 749 (74.2) & $757(71.9)$ & 0.23 \\
\hline \multicolumn{2}{|c|}{ RAS blocker } & $640(63.4)$ & $698(66.3)$ & 0.17 \\
\hline \multicolumn{2}{|l|}{ NSAID } & $20(2.0)$ & $16(1.5)$ & 0.42 \\
\hline \multicolumn{2}{|c|}{ Proton pump inhibitor } & $430(42.6)$ & $580(55.1)$ & $<0.001$ \\
\hline \multicolumn{5}{|c|}{ Medication at 1 year } \\
\hline \multicolumn{2}{|l|}{ Aspirin } & $944(93.6)$ & $982(93.3)$ & 0.66 \\
\hline \multicolumn{2}{|l|}{ DAPT } & $916(90.8)$ & $947(89.9)$ & \multirow{3}{*}{0.69} \\
\hline \multicolumn{2}{|c|}{ with clopidogrel } & $794(78.7)$ & $184(17.5)$ & \\
\hline \multicolumn{2}{|c|}{ with ticagrelor } & $122(12.1)$ & $763(72.5)$ & \\
\hline \multicolumn{2}{|c|}{$\mathrm{OAC}+\mathrm{P} 2 \mathrm{Y}_{12}$ inhibitor } & $42(4.2)$ & $30(2.9)$ & 0.20 \\
\hline \multicolumn{5}{|c|}{$\begin{array}{l}\text { Values are n (\%), or mean } \pm \text { SD. Co-Cr SES: cobalt-chromium sirolimus-eluting stent; } \mathrm{Co-Cr} \\
\text { ZES: cobalt-chromium zotarolimus-eluting stent; DAPT: dual antiplatelet therapy; } \\
\text { DES: drug-eluting stent; NSAID: non-steroidal anti-inflammatory drug; OAC: oral } \\
\text { anticoagulant; Pt-Cr EES: platinum-chromium everolimus-eluting stent; RAS } \\
\text { blocker: renin-angiotensin system blocker }\end{array}$} \\
\hline
\end{tabular}

During the TP, 894/1,053 (84.9\%) patients were on ticagrelor and 159/1,053 (15.1\%) on clopidogrel. At one-year followup, 947/1,053 (89.9\%) patients were still on DAPT: $17.5 \%$ used clopidogrel and $72.5 \%$ ticagrelor; an oral anticoagulant plus $\mathrm{P} 2 \mathrm{Y}_{12}$ inhibitor was prescribed in 30/1,053 (2.9\%) patients.

Reasons for deviation from the primary DAPT regimen at baseline are presented in Supplementary Table 1. The main reason for ticagrelor use during the $\mathrm{CP}$ was that DAPT was initiated in referring hospitals. During the TP, clopidogrel was primarily used because of DAPT initiation in referring hospitals or at the discretion of treating physicians (without written motivation).

\section{CLINICAL OUTCOME}

One-year clinical follow-up was available in 2,048/2,062 (99.3\%) patients (seven lost in each period). Data of 30-day, and 30-day to one-year outcomes are presented in Supplementary Table 2.
Table 3 reports one-year outcomes of various clinical endpoints during the CP and TP. The composite primary endpoint NACCE occurred in 51/1,009 (5.1\%) CP patients versus 81/1,053 (7.8\%) TP patients (HR 1.53 [95\% CI: 1.08-2.17], p=0.02). Assessment of non-inferiority of TP versus $\mathrm{CP}$ resulted in inconclusive findings (risk difference 2.64 [95\% CI: $0.52-4.77], \mathrm{p}_{\text {non-inferiority }}=0.48$ ). The higher NACCE rate in TP patients was largely caused by a difference in major bleeding $(1.2 \%$ vs. $2.7 \%, p=0.02)$. There was no significant difference in the individual endpoints all-cause death, MI, and stroke; the same applied to the composite of cardiac death, MI or stroke ( $3.7 \%$ vs. $4.7 \%, p=0.27)$. Figure 2 and Figure 3 display the time-to-event curves for the primary endpoint NACCE and its individual components. During the CP and TP, rates of definite $(0.3 \%$ vs. $0.6 \% ; \mathrm{p}=0.35)$ and definite or probable stent thrombosis $(0.6 \%$ vs. $0.8 \% ; \mathrm{p}=0.65)$ were low.

Propensity score-adjusted multivariate analysis confirmed significantly higher rates of NACCE (adjusted HR 1.75, $\mathrm{p}=0.003$ ) and major bleeding (adjusted HR 2.75, $\mathrm{p}=0.01$ ) during the TP (Table 3).

\section{SENSITIVITY ANALYSIS}

Supplementary Table 3 and Supplementary Table 4 present the baseline characteristics of the study population of the sensitivity analysis; clinical outcomes are presented in Table 4. In clopidogreltreated patients during the $\mathrm{CP}$ versus ticagrelor-treated patients during the TP, the NACCE rate was $5.2 \%$ vs. $7.0 \%$ (HR 1.33 [95\% CI: $0.92-1.99$ ], $\mathrm{p}=0.12$ ); the risk difference was 1.80 [95\% CI: -0.43 $\left.4.06], \mathrm{p}_{\text {non-inferiority }}=0.21\right)$. There was a significantly higher incidence of major bleeding in ticagrelor-treated patients during the TP $(1.1 \%$ vs. $2.7 \%$, HR 2.36 [95\% CI: 1.13-4.93], $\mathrm{p}=0.02$ ).

After propensity score-adjusted multivariate analysis, this difference in major bleeding was still significant (adjusted HR 2.77 [95\% CI: 1.27-6.07], $\mathrm{p}=0.01$ ), while for NACCE the numeric difference did not reach statistical significance (adjusted HR 1.49 [95\% CI: 0.99-2.26], $\mathrm{p}=0.06)$.

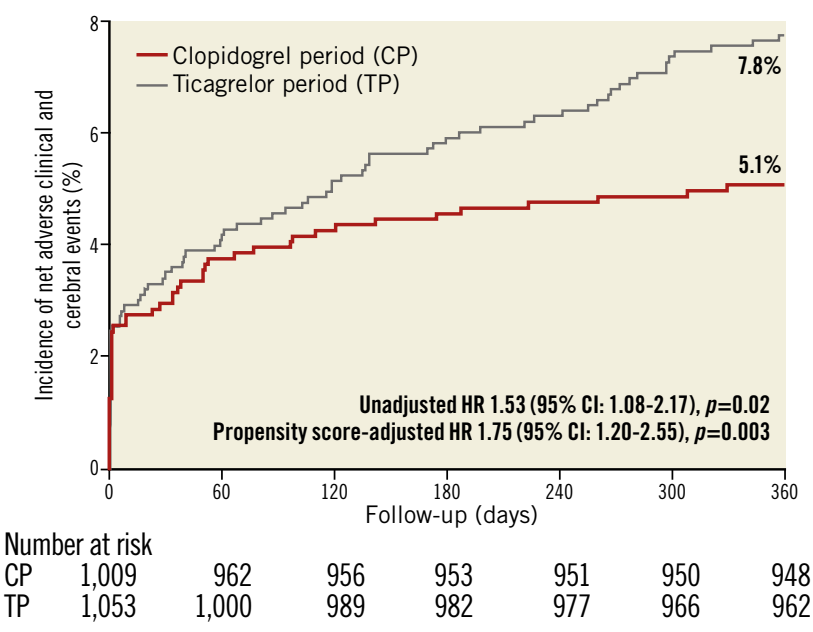

Figure 2. One-year Kaplan-Meier cumulative incidence curves for the primary endpoint NACCE. CI: confidence interval; HR: hazard ratio; NACCE: net adverse clinical and cerebral events 
A

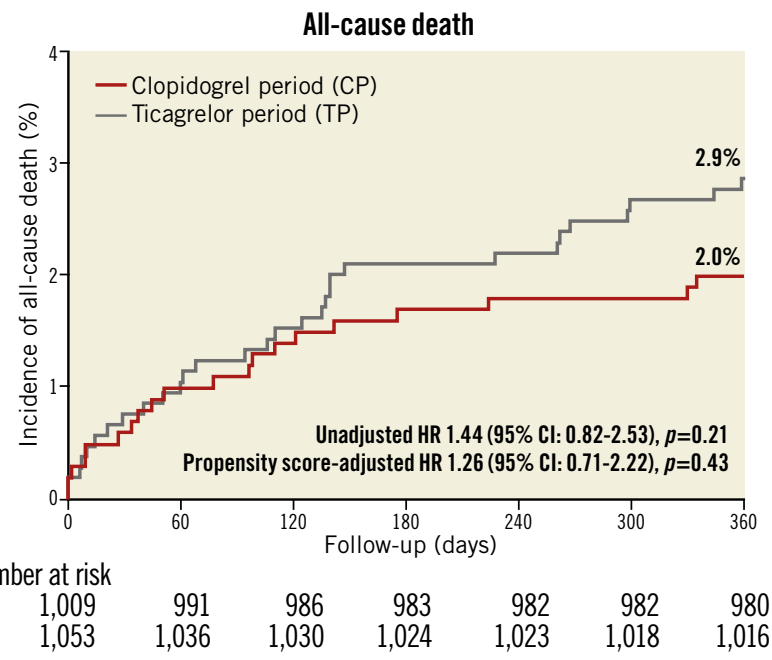

C

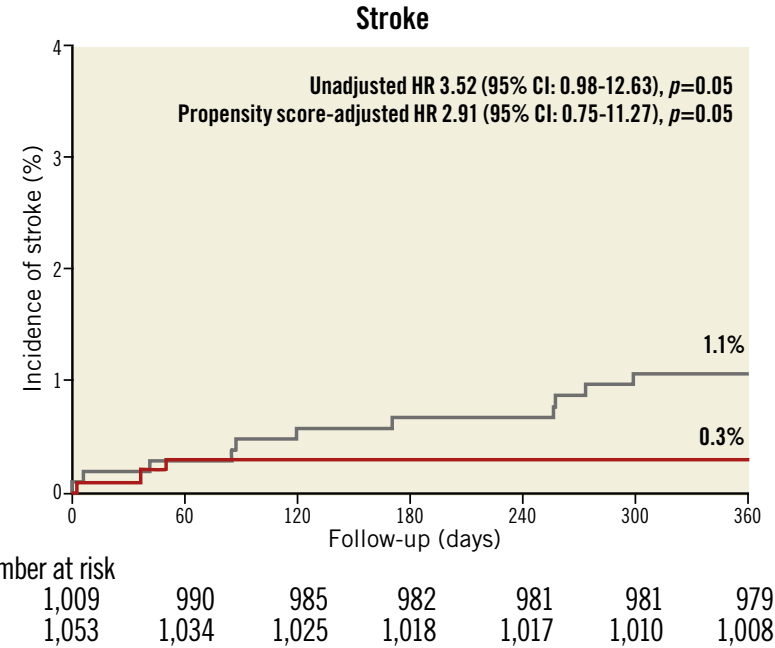

B

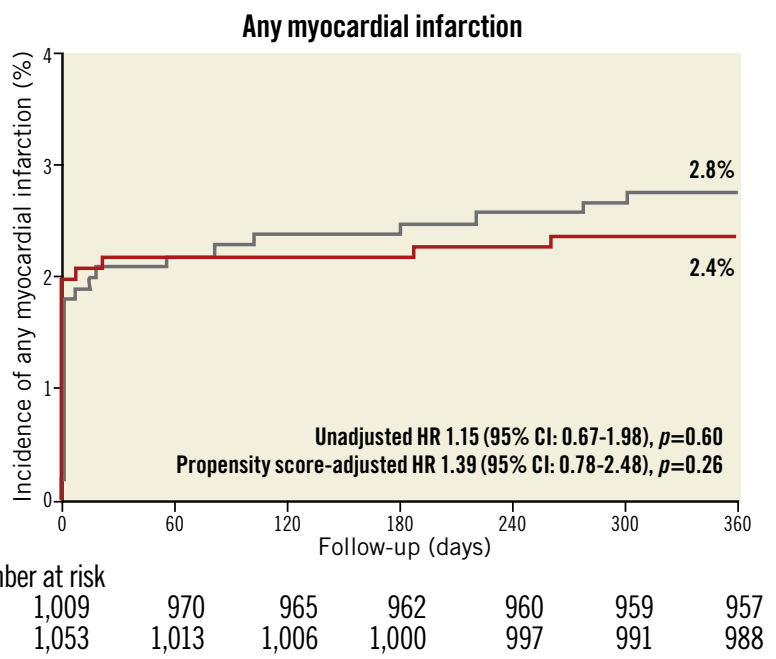

D

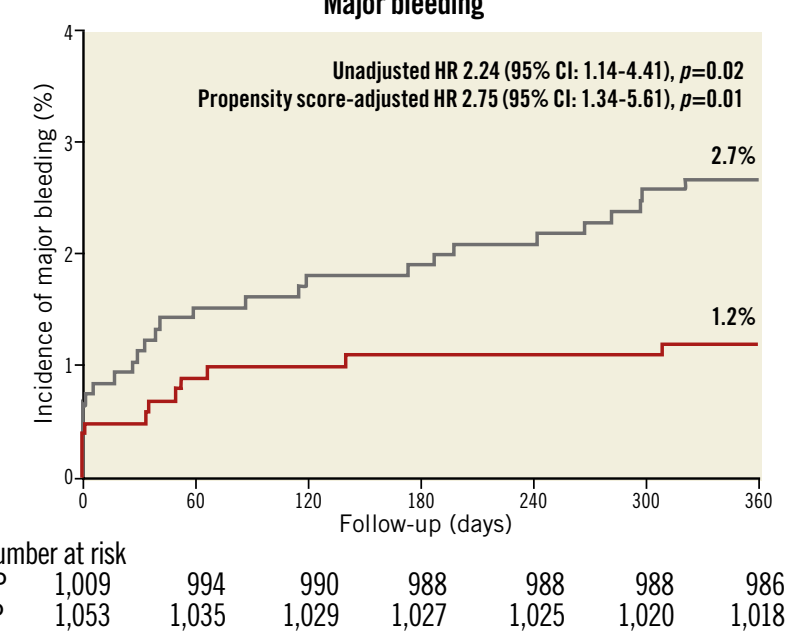

Figure 3. One-year Kaplan-Meier cumulative incidence curves for the individual components of the primary endpoint. A) All-cause death. B) Any myocardial infarction. C) Stroke. D) Major bleeding. CI: confidence interval; HR: hazard ratio

\section{Discussion}

Patients treated during the TP had significantly higher rates of the primary endpoint NACCE as compared to CP patients, and non-inferiority assessment of the ticagrelor-based primary DAPT regimen (as compared to clopidogrel-based DAPT) showed inconclusive results. During the TP there were significantly more major bleedings. The rates of all-cause death, MI and stroke showed no statistically significant difference between treatment periods. Propensity scoreadjusted multivariate analyses demonstrated that treatment during the TP was an independent predictor of NACCE and major bleedings. Patients treated with ticagrelor during the TP had a significantly higher risk of major bleedings than patients treated with clopidogrel during the $\mathrm{CP}$, while there was no difference in ischaemic outcomes.

International guidelines recommend the use of ticagrelor over clopidogrel in all ACS patients merely based on the PLATO (PLATelet Inhibition and Patient Outcomes) trial, in which ticagrelor-treated STEMI and other moderate to high-risk ACS patients had significantly lower rates of vascular death and MI than clopidogrel-treated patients ${ }^{3}$. In a recent meta-analysis, STEMI patients undergoing PCI were found to have a lower mortality and fewer major adverse cardiac events if ticagrelor-based DAPT was used; however, this was mainly driven by data from PLATO with marginal additional input from a few small-sized studies with short duration (1-3 months) of DAPT and follow-up ${ }^{16}$. In contrast to PLATO, the randomised PHILO trial found non-significantly higher rates of major adverse cardiovascular events and major bleeding in Asian ACS patients treated with ticagrelor versus clopidogrel ${ }^{17}$.

Randomised controlled trials are considered the gold standard of clinical research, but they only have limited external validity, as trial participants frequently differ from patients in a real-world setting. For instance, participants in randomised trials with unregistered drugs may represent a special category of patients, who are likely to have a better medication adherence than patients in "realworld" registries ${ }^{3,18}$. Therefore, positive findings of randomised controlled trials should be confirmed in broader patient populations, as are examined in large real-world registries, which provide 
Table 3. One-year clinical outcome.

\begin{tabular}{|c|c|c|c|c|c|c|}
\hline & \multicolumn{2}{|c|}{ All patients $(n=2,062)$} & \multirow[b]{2}{*}{$\begin{array}{l}\text { Unadjusted hazard } \\
\text { ratio }(95 \% \mathrm{CI})\end{array}$} & \multirow[b]{2}{*}{$p$-value } & \multirow[b]{2}{*}{$\begin{array}{l}\text { Propensity score- } \\
\text { adjusted hazard ratio } \\
(95 \% \mathrm{CI})\end{array}$} & \multirow[b]{2}{*}{$p$-value } \\
\hline & $\begin{array}{l}\text { Clopidogrel } \\
\text { period (CP) } \\
n=1,009\end{array}$ & $\begin{array}{c}\text { Ticagrelor } \\
\text { period (TP) } \\
n=1,053\end{array}$ & & & & \\
\hline NACCE & $51(5.1)$ & $81(7.8)$ & $1.53(1.08-2.17)$ & 0.02 & $1.75(1.20-2.55)$ & 0.003 \\
\hline All-cause death & $20(2.0)$ & $30(2.9)$ & $1.44(0.82-2.53)$ & 0.21 & $1.61(0.88-2.95)$ & 0.12 \\
\hline Any MI & $24(2.4)$ & $29(2.8)$ & $1.15(0.67-1.98)$ & 0.60 & $1.39(0.78-2.48)$ & 0.26 \\
\hline Stroke & $3(0.3)$ & $11(1.1)$ & $3.52(0.98-12.63)$ & 0.05 & $2.91(0.75-11.27)$ & 0.12 \\
\hline Ischaemic & $3(0.3)$ & $7(0.7)$ & & & & \\
\hline Haemorrhagic & $0(0.0)$ & $4(0.4)$ & & & & \\
\hline Major bleeding* & $12(1.2)$ & $28(2.7)$ & $2.24(1.14-4.41)$ & 0.02 & $2.75(1.34-5.61)$ & 0.01 \\
\hline Gastrointestinal & $6(0.6)$ & $13(1.2)$ & & & & \\
\hline Intracranial & $0(0.0)$ & $4(0.4)$ & & & & \\
\hline Access-site & $1(0.1)$ & $4(0.4)$ & & & & \\
\hline Other & $5(0.5)$ & $9(0.9)$ & & & & \\
\hline Cardiac death, MI, or stroke & $37(3.7)$ & $49(4.7)$ & $1.27(0.83-1.94)$ & 0.27 & $1.33(0.84-2.11)$ & 0.22 \\
\hline Any revascularisation $(\mathrm{PCl} \text { or } \mathrm{CABG})^{\pi}$ & $41(4.2)$ & $56(5.4)$ & $1.32(0.88-1.97)$ & 0.18 & $1.31(0.85-2.03)$ & 0.22 \\
\hline Any revascularisation by $\mathrm{PCl}$ & $29(3.0)$ & $42(4.1)$ & $1.40(0.87-2.25)$ & 0.16 & $1.48(0.89-2.46)$ & 0.13 \\
\hline Any revascularisation by $\mathrm{CABG}$ & $13(1.3)$ & $15(1.5)$ & $1.11(0.53-2.34)$ & 0.78 & $0.97(0.43-2.18)$ & 0.95 \\
\hline Definite or probable stent thrombosis & $6(0.6)$ & $8(0.8)$ & $1.28(0.44-3.69)$ & 0.65 & $1.03(0.33-3.27)$ & 0.96 \\
\hline Definite stent thrombosis ${ }^{\ddagger}$ & $3(0.3)$ & $6(0.6)$ & $1.92(0.48-7.67)$ & 0.35 & $1.64(0.37-7.34)$ & 0.52 \\
\hline \multicolumn{7}{|c|}{ 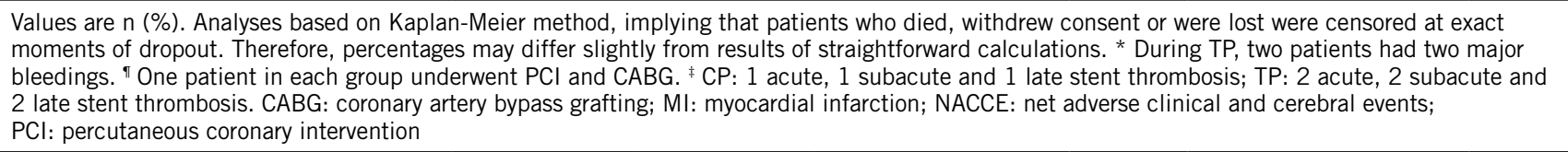 } \\
\hline
\end{tabular}

Table 4. One-year clinical outcome for the sensitivity analysis.

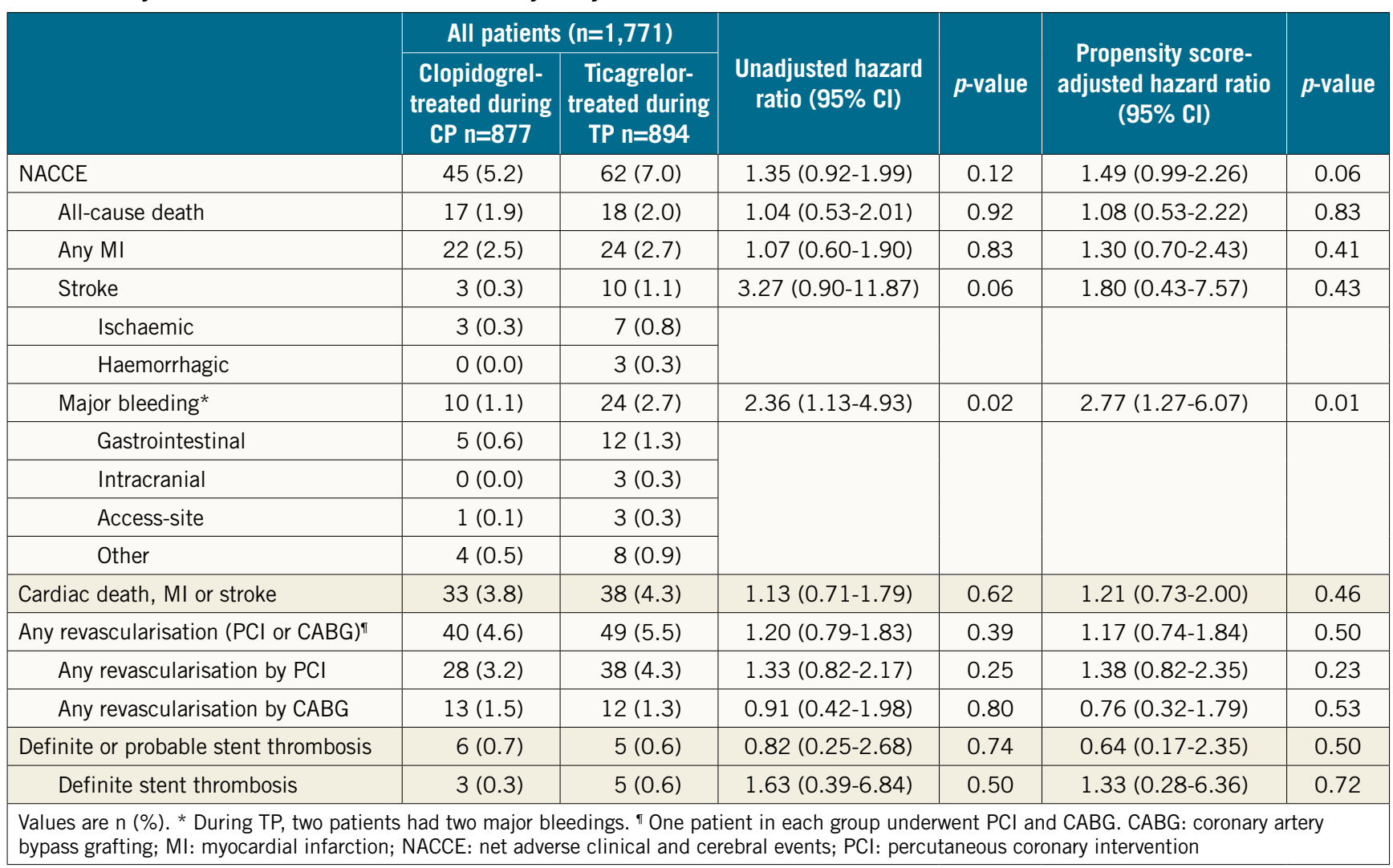


complementary information. In the 45,073 ACS patients of the realworld SWEDEHEART registry, treated with or without PCI, comparable results to PLATO were found with a lower mortality in patients on ticagrelor ${ }^{19}$; however, in SWEDEHEART, ticagrelor was preferentially used in patients at low risk of bleeding and death (indicated by lower CRUSADE and GRACE scores) ${ }^{20}$, and patients on ticagrelor were significantly more often assessed by coronary angiography and treated by $\mathrm{PCI}^{19,20}$. Furthermore, in the GRAPE registry, which examined ACS patients treated by PCI, ticagrelor- and clopidogreltreated patients showed similar major adverse cardiac event rates ${ }^{21}$. These studies suggest that, so far, no equivocal decision can be made on whether ticagrelor is superior in real-world clinical practice.

The main findings of CHANGE DAPT corroborate results of the recent TOPIC trial, which showed no differences in ischaemic outcomes at one-year follow-up between more potent P2 $\mathrm{Y}_{12}$ inhibitorversus clopidogrel-treated ACS patients, and a net clinical benefit for switching to clopidogrel-based DAPT ${ }^{22}$. In the TOPIC study, ACS patients treated by PCI were randomised after one month of DAPT with more potent $\mathrm{P} 2 \mathrm{Y}_{12}$ inhibitors, to continued treatment with the potent $\mathrm{P} 2 \mathrm{Y}_{12}$ inhibitor until 12 months, or to switching to clopidogrel. The main outcome consisted of a net clinical benefit for the switched group, primarily driven by a significantly higher bleeding risk in patients with a continued potent $\mathrm{P} 2 \mathrm{Y}_{12}$ inhibitor ${ }^{22}$. Furthermore, a preliminary analysis of SCAAR registry data in 12,168 patients from Västra Götaland County, treated for ACS with PCI, also found no mortality benefit for ticagrelor use, but major bleedings were not assessed (Omerovic E. Ticagrelor is not superior to clopidogrel in patients with acute coronary syndrome: a report from SCAAR. Presented at: EuroPCR 2017, Paris, France, 18 May 2017. Available at https://www.pcronline.com/ Cases-resources-images/Resources/Course-videos-slides/2017/ Antiplatelet-regimen-after-PCI-an-ongoing-debate [last visited July 24, 2017]).

The higher rates of major bleedings for ticagrelor-treated patients in the present study are in line with other studies ${ }^{3,19,21}$, but were not associated with an increased mortality, as observed by others ${ }^{23,24}$. In CHANGE DAPT, ticagrelor-treated patients had a higher bleeding risk despite more transradial procedures and less glycoprotein IIb/IIIa inhibitor use - two factors known to reduce periprocedural bleedings. Furthermore, during the TP, proton pump inhibitors were more frequently prescribed to prevent gastrointestinal bleedings - the most common type of major bleedings.

Stroke rates during the $\mathrm{CP}$ were comparable to OPTIMIZE ${ }^{15}$ and during the TP similar to PLATO ${ }^{3}$. During both DAPT periods, revascularisation and stent thrombosis rates were generally low and did not differ significantly between groups. The low event rates could well be attributed to experienced operators, liberal use of stent post-dilation and use of newer-generation DES only.

\section{Limitations}

Inherent to the study design, patients were not randomised. During both DAPT periods, certain patients were treated with the other $\mathrm{P}_{12} \mathrm{Y}_{12}$ inhibitor. Although there were only a few differences in baseline characteristics, and propensity score-adjusted multivariate analyses were performed to adjust for potential confounders, residual confounding cannot be excluded. In addition, our study was not powered for detecting differences in clinical outcome with low event rates such as death, stroke, and stent thrombosis.

Despite $>99 \%$ follow-up in our study, which limits the probability of event underreporting, ischaemic and bleeding events were lower than in previous randomised DAPT trials ${ }^{3}$. Nevertheless, this is in line with the low event rates of our randomised stent trials, in which the vast majority of PCI procedures were performed by senior operators with large individual experience ${ }^{9,14}$. Moreover, the NACCE rate was comparable to OPTIMIZE ${ }^{15}$ on which the power calculation of CHANGE DAPT was based. Other contemporary registries in real-world STEMI patients also showed lower event rates than in phase III studies ${ }^{25}$. These differences may be partially explained by ascertainment bias and by dissimilarities in study design, endpoint definition, and patient population. The PLATO trial, for instance, comprised ACS patients treated by optimal medical therapy, PCI or bypass surgery; of all the patients treated by PCI, more than $60 \%$ received BMS only ${ }^{3}$. As BMS use increases major adverse cardiac event risk ${ }^{6,7,26}$, the exclusive use of newer-generation DES in our study could have lowered the MI and revascularisation rates; the latter may have contributed to the lower bleeding rates observed. CHANGE DAPT findings should not be generalised to ACS patients who undergo non-PCI-based treatment.

\section{Conclusions}

In this observational study, the guideline-recommended primary DAPT regimen was associated with an increased adverse event risk in consecutive ACS patients, treated by PCI with newer-generation DES. The difference in event risk was primarily driven by the rate of major bleeding. Assessment of non-inferiority of ticagrelor-based DAPT for the primary endpoint NACCE was inconclusive.

\section{Impact on daily practice}

Based on international guidelines, ticagrelor has largely replaced clopidogrel as a component of DAPT in ACS patients. CHANGE DAPT confirms that treatment with ticagrelor is associated with more major bleedings. This increased bleeding risk should be balanced against benefits in reducing ischaemic events, as previously found in broad populations of ACS patients. Nevertheless, in ACS patients treated by PCI with newer-generation DES, the benefits of ticagrelor in reducing ischaemic events have not yet been demonstrated. In CHANGE DAPT these benefits were not observed, but we cannot exclude that certain subgroups of PCI patients, treated with contemporary DES, may benefit from ticagrelor use.

\section{Funding}

The CHANGE DAPT study was performed without external funding. The research department of Thoraxcentrum Twente has 
received research grants provided by AstraZeneca, Biotronik, Boston Scientific, and Medtronic. Data acquisition was partially supported by an unrestricted research grant from AstraZeneca.

\section{Conflict of interest statement}

P. Zocca has received a lecture fee from AstraZeneca. The other authors have no conflicts of interest to declare.

\section{References}

1. Task Force on the management of ST-segment elevation acute myocardial infarction of the European Society of Cardiology, Steg PG, James SK, Atar D, Badano LP, Lundqvist CB, Borger MA, Di Mario C, Dickstein K, Ducrocq G, Fernandez-Aviles F, Gershlick AH, Giannuzzi P, Halvorsen S, Huber K, Juni P, Kastrati A, Knuuti J, Lenzen MJ, Mahaffey KW, Valgimigli M, van 't Hof A, Widimsky P, Zahger D. ESC Guidelines for the management of acute myocardial infarction in patients presenting with ST-segment elevation. Eur Heart J. 2012;33:2569-619.

2. Roffi M, Patrono C, Collet JP, Mueller C, Valgimigli M, Andreotti F, Bax JJ, Borger MA, Brotons C, Chew DP, Gencer B, Hasenfuss G, Kjeldsen K, Lancellotti P, Landmesser U, Mehilli J, Mukherjee D, Storey RF, Windecker S. 2015 ESC Guidelines for the management of acute coronary syndromes in patients presenting without persistent ST-segment elevation: Task Force for the Management of Acute Coronary Syndromes in Patients Presenting without Persistent ST-Segment Elevation of the European Society of Cardiology (ESC). Eur Heart J. 2016;37:267-315.

3. Wallentin L, Becker RC, BudajA, Cannon CP, Emanuelsson H, Held C, Horrow J, Husted S, James S, Katus H, Mahaffey KW, Scirica BM, Skene A, Steg PG, Storey RF, Harrington RA; for the PLATO Investigators. Ticagrelor versus clopidogrel in patients with acute coronary syndromes. $N$ Engl J Med. 2009;361:1045-57.

4. Becker RC, Bassand JP, Budaj A, Wojdyla DM, James SK, Cornel JH, French J, Held C, Horrow J, Husted S, Lopez-Sendon J, Lassila R, Mahaffey KW, Storey RF, Harrington RA, Wallentin L. Bleeding complications with the $\mathrm{P} 2 \mathrm{Y}_{12}$ receptor antagonists clopidogrel and ticagrelor in the PLATelet inhibition and patient Outcomes (PLATO) trial. Eur Heart J. 2011;32:2933-44.

5. Piccolo R, Pilgrim T, Heg D, Franzone A, Rat-Wirtzler J, Räber L, Silber S, Serruys PW, Jüni P, Windecker S. Comparative effectiveness and safety of new-generation versus early-generation drug-eluting stents according to complexity of coronary artery disease: a patient-level pooled analysis of 6,081 patients. JACC Cardiovasc Interv. 2015;8:1657-66.

6. Palmerini T, Benedetto U, Biondi-Zoccai G, Della Riva D, Bacchi-Reggiani L, Smits PC, Vlachojannis GJ, Jensen LO, Christiansen EH, Berencsi K, Valgimigli M, Orlandi C, Petrou M, Rapezzi C, Stone GW. Long-term safety of drug-eluting and baremetal stents: evidence from a comprehensive network meta-analysis. J Am Coll Cardiol. 2015;65:2496-507.

7. Bønaa KH, Mannsverk J, Wiseth R, Aaberge L, Myreng Y, Nygård $\mathrm{O}$, Nilsen DW, Kløw NE, Uchto $\mathrm{M}$, Trovik T, Bendz B, Stavnes S, Bjørnerheim R, Larsen AI, Slette M, Steigen T,
Jakobsen OJ, Bleie Ø, Fossum E, Hanssen TA, Dahl-Eriksen Ø, Njølstad I, Rasmussen K, Wilsgaard T, Nordrehaug JE; NORSTENT Investigators. Drug-eluting or bare-metal stents for coronary artery disease. N Engl J Med. 2016;375:1242-52.

8. von Birgelen $\mathrm{C}$, Basalus $\mathrm{MW}$, Tandjung $\mathrm{K}$, van Houwelingen KG, Stoel MG, Louwerenburg JW, Linssen GC, Saïd SA, Kleijne MA, Sen H, Löwik MM, van der Palen J, Verhorst PM, de Man FH. A randomized controlled trial in secondgeneration zotarolimus-eluting Resolute stents versus everolimuseluting Xience V stents in real-world patients: the TWENTE trial. $J$ Am Coll Cardiol. 2012;59:1350-61.

9. von Birgelen C, Sen H, Lam MK, Danse PW, Jessurun GA, Hautvast RW, van Houwelingen GK, Schramm AR, Gin RM, Louwerenburg JW, de Man FH, Stoel MG, Löwik MM, Linssen GC, Saïd SA, Nienhuis MB, Verhorst PM, Basalus MW, Doggen CJ, Tandjung K. Third-generation zotarolimus-eluting and everolimuseluting stents in all-comer patients requiring a percutaneous coronary intervention (DUTCH PEERS): a randomised, single-blind, multicentre, non-inferiority trial. Lancet. 2014;383:413-23.

10. Cutlip DE, Windecker S, Mehran R, Boam A, Cohen DJ, van Es GA, Steg PG, Morel MA, Mauri L, Vranckx P, McFadden E, Lansky A, Hamon M, Krucoff MW, Serruys PW. Clinical end points in coronary stent trials: a case for standardized definitions. Circulation. 2007;115:2344-51.

11. Vranckx P, Cutlip DE, Mehran R, Kint PP, Silber S, Windecker S, Serruys PW. Myocardial infarction adjudication in contemporary all-comer stent trials: balancing sensitivity and specificity. Addendum to the historical MI definitions used in stent studies. EuroIntervention. 2010;5:871-4.

12. Mehran R, Rao SV, Bhatt DL, Gibson CM, Caixeta A, Eikelboom J, Kaul S, Wiviott SD, Menon V, Nikolsky E, Serebruany V, Valgimigli M, Vranckx P, Taggart D, Sabik JF, Cutlip DE, Krucoff MW, Ohman EM, Steg PG, White H. Standardized bleeding definitions for cardiovascular clinical trials: a consensus report from the Bleeding Academic Research Consortium. Circulation. 2011;123:2736-47.

13. Bovill EG, Terrin ML, Stump DC, Berke AD, Frederick M, Collen D, Feit F, Gore JM, Hillis LD, Lambrew CT, et al. Hemorrhagic events during therapy with recombinant tissue-type plasminogen activator, heparin, and aspirin for acute myocardial infarction. Results of the Thrombolysis in Myocardial Infarction (TIMI), Phase II Trial. Ann Intern Med. 1991;115:256-65.

14. von Birgelen C, Kok MM, van der Heijden LC, Danse PW, Schotborgh CE, Scholte M, Gin RMTJ, Somi S, van Houwelingen KG, Stoel MG, de Man FHAF, Louwerenburg JHW, Hartmann M, Zocca P, Linssen GCM, van der Palen J, Doggen CJM, Löwik MM. Very thin strut biodegradable polymer everolimuseluting and sirolimus-eluting stents versus durable polymer zotarolimus-eluting stents in allcomers with coronary artery disease (BIO-RESORT): a three-arm, randomised, non-inferiority trial. Lancet. 2016;388:2607-17.

15. Feres F, Costa RA, Abizaid A, Leon MB, Marin-Neto JA, Botelho RV, King SB 3rd, Negoita M, Liu M, de Paula JE, 
Mangione JA, Meireles GX, Castello HJ, Nicolela EL, Perin MA, Devito FS, Labrunie A, Salvadori D Jr, Gusmão M, Staico R, Costa JR Jr, de Castro JP, Abizaid AS, Bhatt DL; OPTIMIZE Trial Investigators. Three vs twelve months of dual antiplatelet therapy after zotarolimus-eluting stents: the OPTIMIZE randomized trial. JAMA. 2013;310:2510-22.

16. Sun J, Xiang Q, Li C, Wang Z, Hu K, Xie Q, Cui Y. Efficacy and safety of novel oral $\mathrm{P} 2 \mathrm{Y}_{12}$ receptor inhibitors in patients with ST-segment elevation myocardial infarction undergoing PCI: a systematic review and meta-analysis. $J$ Cardiovasc Pharmacol. 2017;69:215-27.

17. Goto S, Huang CH, Park SJ, Emanuelsson H, Kimura T. Ticagrelor vs. clopidogrel in Japanese, Korean and Taiwanese patients with acute coronary syndrome - randomized, double-blind, phase III PHILO study. Circ J. 2015;79:2452-60.

18. Bergmeijer TO, Janssen PWA, van Oevelen M, van Rooijen D, Godschalk TC, Kelder JC, Deneer VHM, Serebruany VL, Ten Berg JM. Incidence and causes for early ticagrelor discontinuation: a "realworld" Dutch registry experience. Cardiology. 2017;138:164-8.

19. Sahlén A, Varenhorst C, Lagerqvist B, Renlund $H$, Omerovic E, Erlinge D, Wallentin L, James SK, Jernberg T. Outcomes in patients treated with ticagrelor or clopidogrel after acute myocardial infarction: experiences from SWEDEHEART registry. Eur Heart J. 2016;37:3335-42.

20. Sahlén A, Varenhorst C, Lagerqvist B, Renlund H, Wallentin L, James SK, Jernberg T. Contemporary use of ticagrelor in patients with acute coronary syndrome: insights from Swedish web system for enhancement and development of evidence-based care in heart disease evaluated according to recommended therapies (SWEDEHEART). Eur Heart $J$ Cardiovasc Pharmacother. 2016;2:5-12.

21. Alexopoulos D, Xanthopoulou I, Deftereos S, Hamilos M, Sitafidis G, Kanakakis I, Pentara I, Vavouranakis M, Davlouros P, Hahalis G, Goudevenos J. Contemporary antiplatelet treatment in acute coronary syndrome patients undergoing percutaneous coronary intervention: 1-year outcomes from the GReek AntiPlatElet (GRAPE) Registry. J Thromb Haemost. 2016;14:1146-54.

22. Cuisset T, Deharo P, Quilici J, Johnson TW, Deffarges S, Bassez C, Bonnet G, Fourcade L, Mouret JP, Lambert M, Verdier V, Morange PE, Alessi MC, Bonnet JL. Benefit of switching dual antiplatelet therapy after acute coronary syndrome: the TOPIC (timing of platelet inhibition after acute coronary syndrome) randomized study. Eur Heart J. 2017 May 16. [Epub ahead of print].
23. Eikelboom JW, Mehta SR, Anand SS, Xie C, Fox KA, Yusuf S. Adverse impact of bleeding on prognosis in patients with acute coronary syndromes. Circulation. 2006;114:774-82.

24. Manoukian SV, Feit F, Mehran R, Voeltz MD, Ebrahimi R, Hamon M, Dangas GD, Lincoff AM, White HD, Moses JW, King SB 3rd, Ohman EM, Stone GW. Impact of major bleeding on 30-day mortality and clinical outcomes in patients with acute coronary syndromes: an analysis from the ACUITY Trial. J Am Coll Cardiol. 2007;49:1362-8.

25. Danchin N, Lettino M, Zeymer U, Widimsky P, Bardaji A, Barrabes JA, Cequier A, Claeys MJ, De Luca L, Dörler J, Erlinge D, Erne P, Goldstein P, Koul SM, Lemesle G, Lüscher TF, Matter CM, Montalescot G, Radovanovic D, Lopez Sendón J, Tousek P, Weidinger F, Weston CF, Zaman A, Andell P, Li J, Jukema JW; PIRAEUS group. Use, patient selection and outcomes of $\mathrm{P}_{2} \mathrm{Y}_{12}$ receptor inhibitor treatment in patients with STEMI based on contemporary European registries. Eur Heart $J$ Cardiovasc Pharmacother. 2016;2:152-67.

26. Räber L, Kelbæk H, Taniwaki M, Ostojic M, Heg D, Baumbach A, von Birgelen C, Roffi M, Tüller D, Engstrøm T, Moschovitis A, Pedrazzini G, Wenaweser P, Kornowski R, Weber K, Lüscher TF, Matter CM, Meier B, Jüni P, Windecker S; COMFORTABLE AMI Trial Investigators. Biolimus-eluting stents with biodegradable polymer versus bare-metal stents in acute myocardial infarction; two-year clinical results of the COMFORTABLE-AMI trial. Circ Cardiovasc Interv. 2014;7: 355-64.

\section{Supplementary data}

Supplementary Table 1. Reasons for deviation from primary DAPT regimen according to treatment period.

Supplementary Table 2. Clinical outcome at 30 days and 30 days to 1 year.

Supplementary Table 3. Baseline characteristics for the sensitivity analysis.

Supplementary Table 4. Procedural characteristics and medication for the sensitivity analysis.

\section{The supplementary data are published online at: http://www.pcronline.com/ eurointervention/125th_issue/184}




\section{Supplementary data}

Appendix Table 1. Reasons for deviation from primary DAPT regimen according to treatment period.

\begin{tabular}{|c|c|c|}
\hline & All patie & $=2,062)$ \\
\hline & $\begin{array}{c}\text { Ticagrelor in the clopidogrel } \\
\text { period (CP) } \\
n=132 / 1,009\end{array}$ & $\begin{array}{c}\text { Clopidogrel in the ticagrelor } \\
\text { period (TP) } \\
n=159 / 1,053\end{array}$ \\
\hline Other P2Y ${ }_{12}$ inhibitor initiated in another referring hospital & $113(85.6)$ & $61(38.4)$ \\
\hline Discretion of the treating physician without written documentation & $6(4.5)$ & $51(32.1)$ \\
\hline Pre-admission use of the other $\mathrm{P}_{2} \mathrm{Y}_{12}$ inhibitor & $0(0.0)$ & $23(14.5)$ \\
\hline Side effects or allergy & $12(9.1)$ & $6(3.8)$ \\
\hline Comorbidity & $0(0.0)$ & $12(7.5)$ \\
\hline Interaction with pre-admission medication & $0(0.0)$ & $2(1.3)$ \\
\hline To promote medication adherence & $0(0.0)$ & $3(1.9)$ \\
\hline History of stent thrombosis & $1(0.8)$ & $0(0.0)$ \\
\hline History of bleeding & $0(0.0)$ & $1(0.6)$ \\
\hline
\end{tabular}

Appendix Table 2. Clinical outcome at $\mathbf{3 0}$ days and $\mathbf{3 0}$ days to 1 year.

\begin{tabular}{|c|c|c|c|c|c|c|}
\hline \multirow[b]{2}{*}{ Clinical outcome } & \multicolumn{2}{|c|}{ All patients $(n=2,062)$} & \multirow{2}{*}{$\begin{array}{l}\text { Unadjusted hazard } \\
\text { ratio ( } 95 \% \text { CI) }\end{array}$} & \multirow[b]{2}{*}{$p$-value } & \multirow{2}{*}{$\begin{array}{l}\text { Propensity score- } \\
\text { adjusted hazard ratio } \\
\text { ( } 95 \% \mathrm{CI})\end{array}$} & \multirow[b]{2}{*}{$p$-value } \\
\hline & $\begin{array}{c}\text { Clopidogrel period (CP) } \\
n=1,009\end{array}$ & $\begin{array}{c}\text { Ticagrelor period (TP) } \\
n=1,053\end{array}$ & & & & \\
\hline \multicolumn{7}{|l|}{30 days } \\
\hline NACCE & $30(3.0)$ & $37(3.5)$ & $1.18(0.73-1.91)$ & 0.50 & $1.37(0.82-2.29)$ & 0.24 \\
\hline All-cause death & $6(0.6)$ & $8(0.8)$ & $1.28(0.44-3.68)$ & 0.65 & $1.25(0.40-3.92)$ & 0.71 \\
\hline Any MI & $22(2.2)$ & $22(2.1)$ & $0.95(0.53-1.72)$ & 0.87 & $1.08(0.57-2.05)$ & 0.81 \\
\hline Stroke & $1(0.1)$ & $2(0.2)$ & $1.92(0.17-21.12)$ & 0.59 & $2.46(0.20-31.16)$ & 0.49 \\
\hline Major bleeding & $5(0.5)$ & $12(1.1)$ & $2.30(0.81-6.54)$ & 0.11 & $3.52(1.19-10.44)$ & 0.02 \\
\hline \multicolumn{7}{|l|}{30 days- 1 year } \\
\hline NACCE & $21(2.2)$ & $44(4.4)$ & $2.03(1.21-3.42)$ & 0.01 & $2.29(1.32-3.99)$ & 0.003 \\
\hline All-cause death & $14(1.4)$ & $21(2.1)$ & $1.44(0.73-2.84)$ & 0.28 & $1.70(0.82-3.50)$ & 0.15 \\
\hline Any MI & $2(0.2)$ & $7(0.7)$ & $3.38(0.70-16.26)$ & 0.11 & $5.25(1.03-26.64)$ & 0.045 \\
\hline Stroke & $2(0.2)$ & $8(0.8)$ & $3.86(0.82-18.16)$ & 0.07 & $3.03(0.59-15.65)$ & 0.19 \\
\hline Major bleeding & $6(0.6)$ & $19(1.9)$ & $3.06(1.22-7.66)$ & 0.01 & $3.30(1.25-8.69)$ & 0.02 \\
\hline
\end{tabular}


Appendix Table 3. Baseline characteristics for the sensitivity analysis.

\begin{tabular}{|c|c|c|c|}
\hline \multirow[b]{2}{*}{ Characteristics } & \multicolumn{2}{|c|}{ All patients $(n=1,171)$} & \multirow[b]{2}{*}{$p$-value } \\
\hline & $\begin{array}{c}\text { Clopidogrel- } \\
\text { treated during } \\
\text { the CP } \\
n=877\end{array}$ & $\begin{array}{c}\text { Ticagrelor- } \\
\text { treated during } \\
\text { the TP } \\
n=894\end{array}$ & \\
\hline Age, years & $62.9 \pm 11.7$ & $62.8 \pm 11.8$ & 0.83 \\
\hline Male sex & $609(69.4)$ & $664(72.0)$ & 0.23 \\
\hline $\mathrm{BMI}, \mathrm{kg} / \mathrm{m}^{2}$ * & $27.3 \pm 4.3$ & $27.7 \pm 4.3$ & 0.08 \\
\hline \multicolumn{4}{|l|}{ Clinical history } \\
\hline Hypertension & $363(41.4)$ & $352(39.4)$ & 0.39 \\
\hline Hypercholesterolaemia & $307(35.0)$ & $309(34.6)$ & 0.85 \\
\hline Diabetes mellitus & $140(16.0)$ & $137(15.3)$ & 0.71 \\
\hline Peripheral artery disease & $76(8.7)$ & $45(5.0)$ & 0.002 \\
\hline $\begin{array}{l}\text { Chronic obstructive pulmonary } \\
\text { disease }\end{array}$ & $68(7.8)$ & $54(6.0)$ & 0.16 \\
\hline Previous MI & $124(14.1)$ & $120(13.4)$ & 0.66 \\
\hline Previous PCl & $143(16.3)$ & $130(14.5)$ & 0.30 \\
\hline Previous CABG & $63(7.2)$ & $40(4.5)$ & 0.02 \\
\hline Previous stroke & $28(3.2)$ & $17(1.9)$ & 0.08 \\
\hline $\begin{array}{l}\text { Previous gastrointestinal } \\
\text { bleeding }\end{array}$ & $10(1.1)$ & $12(1.3)$ & 0.70 \\
\hline Renal insufficiency" & $36(4.1)$ & $27(3.0)$ & 0.22 \\
\hline Dialysis & $9(1.0)$ & $3(0.3)$ & 0.08 \\
\hline \multicolumn{4}{|l|}{ Clinical presentation } \\
\hline ST-elevation MI & 407 (46.4) & $403(45.1)$ & 0.57 \\
\hline Non-ST-elevation MI & $207(23.6)$ & $264(29.5)$ & 0.01 \\
\hline Unstable angina & $263(30.0)$ & $227(25.4)$ & 0.03 \\
\hline \multicolumn{4}{|c|}{$\begin{array}{l}\text { Values are } n(\%) \text { or mean } \pm S D \text {. * } 0 \text { ut of } 1,648 \text { patients. " Defined by creatinine }>130 \mu \mathrm{mol} / / \\
(0.15 \mathrm{mg} / \mathrm{dL} \text { ). BMI: body mass index; CABG: coronary artery bypass grafting; MI: myocardial } \\
\text { infarction; PCl: percutaneous coronary intervention }\end{array}$} \\
\hline
\end{tabular}

Appendix Table 4. Procedural characteristics and medication for the sensitivity analysis.

\begin{tabular}{|c|c|c|c|c|}
\hline \multirow{2}{*}{\multicolumn{2}{|c|}{ Characteristics }} & \multicolumn{2}{|c|}{ All patients $(n=1,771)$} & \multirow[b]{2}{*}{$p$-value } \\
\hline & & $\begin{array}{l}\text { Clopidogrel- } \\
\text { treated during } \\
\text { the CP } \\
n=877\end{array}$ & $\begin{array}{l}\text { Ticagrelor- } \\
\text { treated during } \\
\text { the TP } \\
n=894\end{array}$ & \\
\hline \multicolumn{5}{|c|}{ Procedural characteristics } \\
\hline \multirow{2}{*}{$\begin{array}{l}\text { Arterial } \\
\text { access }\end{array}$} & Radial & $145(16.5)$ & $408(45.6)$ & \multirow{2}{*}{$<0.001$} \\
\hline & Femoral & $732(83.5)$ & $486(54.4)$ & \\
\hline \multirow{3}{*}{$\begin{array}{l}\text { Vessel } \\
\text { disease }\end{array}$} & 1 & $479(54.6)$ & $519(58.1)$ & \multirow{3}{*}{0.34} \\
\hline & 2 & $264(30.1)$ & $246(27.5)$ & \\
\hline & 3 & $134(15.3)$ & $129(14.4)$ & \\
\hline \multicolumn{2}{|c|}{ Multivessel treatment } & $149(17.0)$ & 150 (16.8) & 0.91 \\
\hline \multicolumn{2}{|c|}{ Glycoprotein Ilb/llla inhibitor } & $392(44.7)$ & 245 (27.4) & $<0.001$ \\
\hline \multirow{4}{*}{$\begin{array}{l}\text { Stent } \\
\text { type }\end{array}$} & Co-Cr SES & $225(25.7)$ & $254(28.4)$ & \multirow{4}{*}{0.10} \\
\hline & $\mathrm{C}_{0}-\mathrm{Cr}$ ZES & $379(43.2)$ & $380(42.5)$ & \\
\hline & Pt-Cr EES & $266(30.3)$ & $259(29.0)$ & \\
\hline & $\begin{array}{l}\text { Other newer- } \\
\text { generation DES }\end{array}$ & $7(0.8)$ & $1(0.1)$ & \\
\hline \multicolumn{5}{|c|}{ Medication at discharge } \\
\hline \multicolumn{2}{|c|}{ Aspirin+clopidogrel } & $877(100)$ & $0(0.0)$ & \\
\hline \multicolumn{2}{|c|}{ Aspirin+ticagrelor } & $0(0.0)$ & $894(100)$ & \\
\hline \multicolumn{2}{|c|}{ Statin } & $836(95.3)$ & $852(95.3)$ & 0.98 \\
\hline \multicolumn{2}{|c|}{ Beta-blocker } & $649(74.0)$ & $632(70.7)$ & 0.12 \\
\hline \multicolumn{2}{|c|}{ RAS blocker } & $554(63.2)$ & $599(67.0)$ & 0.09 \\
\hline \multicolumn{2}{|l|}{ NSAID } & $18(2.1)$ & $12(1.3)$ & 0.25 \\
\hline \multicolumn{2}{|c|}{ Proton pump inhibitor } & $366(41.7)$ & $485(54.3)$ & $<0.001$ \\
\hline \multicolumn{5}{|c|}{ Medication at 1 year } \\
\hline \multicolumn{2}{|c|}{ Aspirin } & $824(94.0)$ & $845(94.5)$ & 0.82 \\
\hline \multicolumn{2}{|l|}{ DAPT } & 800 (91.2) & $816(91.3)$ & 0.99 \\
\hline \multicolumn{2}{|c|}{ with clopidogrel } & $791(90.2)$ & $58(6.5)$ & \\
\hline \multicolumn{2}{|c|}{ with ticagrelor } & $9(1.0)$ & $758(84.8)$ & \\
\hline \multicolumn{2}{|c|}{ 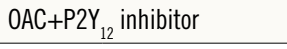 } & $36(4.1)$ & $20(2.2)$ & 0.08 \\
\hline \multicolumn{5}{|c|}{$\begin{array}{l}\text { Values are n (\%). Co-Cr SES: cobalt-chromium sirolimus-eluting stent; } \\
\text { Co-Cr ZES: cobalt-chromium zotarolimus-eluting stent; DAPT: dual antiplatelet therapy; } \\
\text { DES: drug-eluting stent; NSAID: non-steroidal anti-inflammatory drug; OAC: oral } \\
\text { anticoagulant; Pt-Cr EES: platinum-chromium everolimus-eluting stent; RAS } \\
\text { blocker: renin-angiotensin system blocker }\end{array}$} \\
\hline
\end{tabular}

